John Y.B. HOOD*

\title{
INIMICI NOSTRI: JEWS AS HERETICS AND HERETICS AS JUDAIZERS IN JEROME AND AUGUSTINE
}

Even when they were fighting they longed for one another. At the nadir of a bitter dispute, Jerome could still write:

"How I wish that I could receive your embrace and enter into deep and intimate conversation with you".

Augustine replied:

"There is no other place in the world I would rather be than at your side, studying with you"2.

Later, when their decade-long quarrel was finally resolved, it left no bitter residue. On the contrary, the two formed a mutual admiration society. Augustine wrote to Jerome:

"Of all the difficulties that beset me in studying difficult questions, none grieves me more than that I am so far away from you. My desire would be to have you present every day, so that I could speak with you about whatever I wished"3.

* Dr John Y.B. Hood - Haymarket, Virginia (USA), the independent scholar; e-mail: jybhood2@ gmail.com.

${ }^{1}$ In Augustine's correspondence. Cf. Augustinus, Epistula 68, 1, ed. K.-D. Daur, CCL 31A, Turnhout 2005, 30, transl. by the author.

2 Ibidem 73, 5, CCL 31A, 47, transl. by the author. The main issues in dispute were Augustine's critique Jerome's translation of the Old Testament from the Hebrew rather than the Greek Septuagint, which Augustine believed was both intrinsically inspired and hallowed by tradition, and his sharp rebuttal of Jerome's view that the Peter-Paul disagreement over eating with Gentiles was staged for didactic purposes and did not reflect a genuine rift. The controversy was greatly complicated by the fact that Augustine's first letter never reached Jerome, while his second was copied, distributed and freely discussed for several years before the original finally reached its intended recipient. The affair is well summarized in J.N.D. Kelly, Jerome: His Life, Writings and Controversies, London 1975, 217-20 and 263-72. For the entire correspondence, with introduction and notes, see J. Schmid, SS. Eusebii Hieronymi et Aurelii Augustini epistulae mutuae, Bonn 1930.

${ }^{3}$ Augustinus, Epistula 166, 1, ed. A. Goldbacher, CSEL 44, Vindobonae - Lipsiae 1904, 546547: "Nihil equidem molestius fero in omnibus angustiis meis, quas patior in difficillimis quaestionibus, quam in tam longinquo tuae caritatis absentiam [...] cotidie praesentem te habere vellem, cum quo loquerer, quicquid vellem", transl. by the author. 
The latter claimed that

"I do not allow a single hour to pass without the mention of your name [...] you are celebrated throughout the world".

In the end, it was a common enemy that brought them together. This was no surprise; both had spent their entire ecclesiastical career engaged in controversy. For Augustine, the polemical treatises came in great career-defining waves: the anti-Manichean works of the 380s and early 390s; the anti-Donatist treatises of the late 390s and early 400s; and the opera magna, the anti-Arian De Trinitate (c. 415), and De civitate Dei (426), his vast refutation of traditional Roman polytheism. For Jerome, the primary targets were Jovinius and others who opposed his exaltation of ascetic celibacy, and those who defended Origen's speculative theology, above all his erstwhile soul-mate, Rufinus of Aquileia. Augustine, who could not read Greek and so did not know Origen directly, wisely steered clear of this battle, though in 405 he did write an ardent letter begging the two friends to stop scandalizing the Church with their philippics ${ }^{5}$.

Both men waged their final war against Pelagianism. For Jerome, it proved merely a brief coda. For Augustine, it became a fifteen-year obsession that inspired him to develop and hone the ideas that would shape, and haunt, western theology for more than a millennium: original sin, predestination, divine sovereignty, and God's irresistible grace.

The British-born layman Pelagius had lived in Rome from about the year 380. There, in his oral teaching as well as in commentaries on Paul's letters, he developed his characteristic doctrines: that Adam's sin had impacted Adam alone; that each human was endowed by God with a nature that was wholly good; and that Christians must earn their salvation by following Christ's example and living lives of perfect moral probity. Over time, this austere teaching, combined with his charisma and personal holiness, won him a substantial following among Rome's Christian aristocracy ${ }^{6}$. Oddly, Augustine seemed scarcely to have heard of Pelagius until he arrived in Carthage in 410, after the sack of Rome. Beginning in 412, however, with The Letter and the Spirit, Augustine initiated a debate with Pelagius and his followers that would end only with his death.

He reached out to Jerome in 415, after he heard that a disciple of Pelagius, the combative Caelestius, had traveled east and won a declaration of doctrinal orthodoxy at a council in Diospolis. The overture included two letters (166 and 167) along with a copy of several of his anti-Pelagian treatises ${ }^{7}$. By then

${ }^{4}$ In Augustine's correspondence. Cf. ibidem 195, ed. A. Goldbacher, CSEL 57, Vindobonae Lipsiae 1911, 215: "Absque tui nominis mentione ne unam quidem horam praeterire patiamur [...] in orbe celebraris", transl. by the author.

${ }^{5}$ Cf. ibidem 73, 10, CCL 31A, 51-52.

${ }^{6}$ Cf. P. Brown, Augustine of Hippo, Berkeley 2000², 341-344.

${ }^{7}$ Cf. Kelly, Jerome, p. 317-18. See also M.H. Williams, The Monk and the Book: Jerome and the Makings of Christian Scholarship, Chicago 2006, 294-299. 
Jerome was acquainted with the new teaching and had even entered into controversy with certain Pelagian monks. Flattered by Augustine's request, eager to bury the hatchet between them, and convinced the cause was right on its merits, he responded with a Dialogue Against Pelagians. The Dialogue closely followed Augustine's theological reasoning and cited his works with extravagant admiration. At its conclusion, however, Jerome begged off further polemical activity. His excuse was an uncharacteristically humble one: it would be superfluous for him to write against the Pelagians since Augustine himself could do so much more effectively ${ }^{8}$.

The joint attack on Pelagianism revealed broad and deep agreements on ecclesiology, soteriology and hermeneutics. Both men believed the church's enemies were essentially three - pagans, Jews and heretics, and that these "persecutors of the body of Christ" shared certain intellectual and ethical flaws. As a result, Jerome and Augustine routinely paired their advocacy of the Gospel with attacks on the Church's enemies - attacks in which intellectual analyses and rhetorical strategy led then to blur thoroughly the boundaries between those enemies. Of those boundaries, the most porous was between Jews and Christian heretics.

Jerome's analysis of Judaism was a thoroughly supersessionist one, rooted in views pioneered by the second-century apologist Justin Martyr and developed fully by the third-century writers Origen of Alexandria and Tertullian of Carthage". Among his core teachings were that a distinction between "spiritual" and "carnal" Israel existed from the time of Abraham; that the Mosaic Law was intended by God to be provisional and temporary; that the Jews en masse were guilty of killing Christ; that with the coming of Jesus as Messiah, the Mosaic Law had been superseded; that the destruction of the Jerusalem Temple and the exile of the Jews from the Holy Land were divine punishments for the Jews' murder of Christ; that these events, along with the spread of Christianity throughout the Mediterranean world and beyond, constituted historical confirmation of supersession; and, finally, that the Jews' unbelief would persist until the end times, when they would finally repent and accept Jesus as Lord.

Alongside supersessionism, however, there are other, surprisingly nuanced elements to Jerome's attitude toward Jews and Judaism. From Origen he learned to value both the Hebrew Bible and rabbinic exegesis. Thus in the $380 \mathrm{~s}$ and 90 s he employed Jewish instructors to teach him the language. Later, after abortive attempts to work with the Greek Septuagint, he eventually decided to

\footnotetext{
${ }^{8}$ Cf. Hieronymus, Dialogi contra Pelagianos 3, 19, ed. C. Moreschini, CCL 80, Turnhout 1990, 123.

${ }^{9}$ The scholarship on supersession is immense. Marcel Simon, Verus Israel (Paris 1948) is a classic, and remains foundational. Two essay collections well summarize the issues and historiography: Jews and Christians: The Parting of the Ways, A.D. 70-135, ed. J.D.B. Dunn, Grand Rapids 1999, and Partings: How Judaism and Christianity Became Two, ed. H. Shanks, Washington 2013. The most recent treatment of Jerome vis-à-vis Jews and Judaism is R.G. Salinero, Biblia y polémica antijudia en Jerónimo, Madrid 2003.
} 
base his own translation of the Old Testament directly on the Hebrew text. In his commentaries on the prophets, he drew frequently on rabbinic tradition, occasionally even opting for the rabbis' reading over those of his Christian predecessors ${ }^{10}$. All this indicates a level of openness to, and interaction with Jewish culture that was without parallel among the Latin Fathers. In addition to his lived acknowledgement of the value (or at least the usefulness) of the continued presence of Jews, Jerome also laid a foundation for theoretical toleration. In comments on Psalm 59:12, for instance, he clearly presupposes both the reality and the desirability of a Jewish presence. Jerome quotes this verse as "And do not kill them, lest your name be forgotten; scatter them in your might (Et non occidas illos, ne forte obliviscantur nominis tui: disperge eos in virtute tua)" "11. He interprets it thus:

"Do not completely destroy the Jews, because they will always be called your people; but disperse them throughout the earth, so that in this manner their pride may be corrected"12.

To be sure, even here Jerome critiques the Jews for their pride, but his indication that they will continue to exist is functionally equivalent to an acknowledgment that they should continue to exist, because such is God's will. Still more notable, given his frequent claims that Christians are the novus et verus Israel, is his claim that the Jews are now and will continue to be called God's people.

Despite this evidence of practical tolerance in his interactions with Jewish scholars, and indications of a general, theoretical acceptance of Jews within Christendom, Jerome is quite clear that they are to be numbered among the inimici Dei. Indeed, the role of their ancestors in Jesus' crucifixion, as well as their perdurant unbelief, makes them the object of special opprobrium. He also claims it links them with those other inveterate enemies of the Church: Christian heretics.

Jerome's Commentary on Hosea, which dates from 406, is an especially rich source of this line of analysis ${ }^{13}$. Thus in glossing Hosea 9:13, he extends John 8:44's charge that Jews are children of Satan to heretics as well:

\footnotetext{
${ }^{10}$ See the nuanced discussion in: Williams, The Monk and the Book, p. 63-131.

${ }^{11}$ An Old Latin version used by Augustine, which has some support in the Greek manuscript tradition, reads "Slay them not, let they forget your law (Ne occideris eos, nequando obliviscantur legis tuae)". Jerome, however, followed the Septuagint and the Masoretic texts. See J. Cohen, Living Letters of the Law, Berkeley 1999, 33 n. 23.

${ }_{12}$ Hieronymus, Commentarioli in Psalmos 58, ed. G. Morin, CCL 72, Turnhout 1959, 212 : "Noli penitus delere Iudaeos, quia populus tuus semper est appellatus: sed in toto eos orbe disperge, ut saltem sic emendati superbire", transl. by the author.

${ }^{13}$ It was in this year that Jerome completed the last of his commentaries on the Minor Prophets. By then he had fully developed his method of providing a dual commentary (ad litteram and allegorical) on both the Hebrew and Septuagint versions of the text. See Williams, The Monk and the Book, p. 114-118.
} 
"Heretics give birth to children of fornication [... and] now educate them for the destroyer - that is, for the Devil"14.

He also attributes to both groups a sociological model in which the clericalintellectual class "seduces" ordinary people into error through the (mis-)interpretation of sacred texts ${ }^{15}$. Doctrinal error, in turn, leads to self-indulgence and sexual licentiousness ${ }^{16}$. Worse still, by luring orthodox Christians into error and schism, heretics, like Jews, "wound the body of Christ"17. In the end, however, their efforts are doomed to fail. Commenting on Hosea 9:16-17 as well as Matthew 3:10 ("Every tree which does not bear fruit shall be cut down and thrown onto the fire"), Jerome offers a subtle description of the processes whereby both Jews and heretics lose their spiritual fecundity and are punished with a form of moral and intellectual exile:

"We are able to say this about all the Jews because their leaders withdrew from God, leading the people to do the same, so that they might demand [Christ's] death. Because of this he expelled them from his household [...] he struck their root and made them wither, and they made no more fruit. For if, while they were adversaries of God, they had seemed to meditate on scripture and the Law and, like beloved children, had brought forth something of knowledge and doctrine from their heart, they would have withered. Instead, God took from them all prophecy, for they would not listen to him, and they wandered among the nations, having neither altar nor home nor their own city [...] No one doubts heretics are unable to produce the fruits of virtue, because they «killed» the Lord, in whom according to the Apostle they should have been planted and established - for if, while they were God's adversaries, they had [borne fruit] and produced something from the womb by their own fecundity, they would have died"18.

Like his older contemporary, Augustine was a thoroughgoing supersessionist and a rhetorical abuser of Jews. Nor do these elements constitute a minor or isolated strand in his work. They appear regularly in his doctrinal and

${ }^{14}$ Hieronymus, Commentariorum in Osee prophetam libri II 9, 13, ed. M. Adriaen, CCL 76, Turnhout 1969, 101: "Haereticos filios fornicationis generarint [...] nunc autem filios suos educit ad interfectorem, hoc est ad diabolum", transl. by the author.

${ }^{15}$ Cf. ibidem II 9, 8-9, CCL 76, 97.

${ }^{16}$ Cf. ibidem II 9, 10, CCL 76, 99.

${ }^{17} \mathrm{Cf}$. ibidem II 9, 14, CCL 76, 102: "Christi corpus lacerat", transl. by the author.

${ }^{18}$ Ibidem II 9, 16-17, CCL 76, 104: "Possumus hoc ipsum et de omnibus Iudaeis dicere quorum quia principes a Deo recesserunt, commoventes populum, ut eum ad mortem expeterent; propterea eiecit eos de domo sua [...] Percusit radicem eorum et exsicavit, et fructum ultra non facient; quod et si fecerint, et visi fuerint scripturam sanctam legemque meditari, et quasi amantissimos filios aliquid scientiae atque doctrinae de suo corde protulerint, adversante Domino, succidentur. Abiecit enim eos Deus omnium prophetarum, quia non audierunt eum; et vagi erunt in nationibus, non habentes altare, non sedem, non civitatem propriam [...] Haereticos fructus facere non posse virtutum, quia Dominum perdiderunt, quo iuxta apostolum radicati esse debuerunt et fundati, nemo dubitat: quod et si fecerint, et aliquos uteri sui fecunditate generarint, Domino adversante, morientur", transl. by the author. 
exegetical writings, and even more frequently in his sermons, especially those on Psalms and the Gospel of John. Along with countless iterations of the standard charges of Jewish hard-heartedness and spiritual blindness, Augustine was especially fond of reminding his congregation that it was the Jews who had insisted upon Jesus' execution and called for the guilt of his blood to be upon them and their children. In his sermons he quotes the Jews' call of crucifige, crucifige! no fewer than 192 times $^{19}$.

Yet despite his incessant anti-Jewish rhetoric, his supersessionism, and his utter lack of interest in the Jewish communities of Hippo Regius and Carthage, Augustine has received rather favorable press from modern historians for his views on Jews ${ }^{20}$. To make their case for his relative tolerance, scholars focus on two specific elements in Augustine's thought. One is his insistence, against much patristic opinion that, in the pre-Christian era, the Mosaic Law was neither punitive nor exclusively prefigurative, but conferred real spiritual benefits. The other is his famous doctrine of Jewish witness, sketched initially in the early Contra Faustum (399), but developed in fullest form after circa 415. The locus classicus is De civitate Dei 18, 46, but the most thorough statement of the doctrine is actually contained in a two-part sermon on Psalm 59. Significantly, in both places the key text is verses 11-12 of that Psalm - the same verses that inspired Jerome:

"How does this prayer - «Slay them not, lest they forget your law?» - apply to them? It means: do not slay those enemies of mine who slew me. Let the Jewish race survive. It has been conquered by the Romans; its city has been destroyed [...] Yet the Jews remain distinct, marked with their sign; they have not been absorbed by their conquerors [...] they abide and have not been killed, because they are necessary to Gentile believers. Why? So that God may give us proof of his mercy by his dealings with our enemies [...]

«Scatter them by your power». This has happened: the Jews have been scattered among all nations, witnesses to their own iniquity and to our truth. They possess the books in which Christ was foretold, and we possess Christ. Now it sometimes happens that some pagan is skeptical when we recount the prophecies about Christ [... In such a case] we prove from the books of the Jews that these things were foretold long ago. So you see: we confute our enemies by means of other enemies"

${ }^{19}$ Cf. B. Shaw, Sacred Violence, Cambridge 2011, 267.

${ }^{20}$ The most prolific and influential exponent of this interpretation is Paula Fredriksen. See especially her Augustine and the Jews, New York 2008).

${ }^{21}$ Augustinus, Enarrationes in Psalmos 58, 21, ed. E. Dekkers - J. Fraipont, CCL 39, Turnhout 1956, 744: “Quid de Iudaeis: «Ne occideris eos, nequando obliviscantur legis tuae?» Istos inimicos meos, ipsos qui me occiderunt, noli tu occidere. Maneat gens Iudaeorum: certe victa est a Romanis, certe deleta civitas eorum [...] Iudaei tamen manent cum signo; nec sic victi sunt, ut a victoribus absorberentur [...] Sunt ergo Iudaei, non sunt occisi, necessarii sunt credentibus gentibus. Quare hoc? Ut demonstret nobis in inimicis nostris misericordiam suam [...] «Disperge eos in virtute tua». Iam 
In an influential analysis, Jeremy Cohen has argued that Augustine's doctrine of Jewish witness consists of six propositions:

1. Jewish exile is a punishment for the rejection of Jesus.

2. Jewish unbelief in Jesus confirms Old Testament prophecy.

3. Jews carry their books in servitude to the Church, thus refuting charges that Christians have forged biblical prophecies of Christ.

4. Jewish perseverance in religious observance (circumcision, Passover etc.) is of testimonial value to the Church.

5. "Slay them not" means Christians must let Jews live as Jews.

6. Christians must continue to refute Jewish arguments, even though Jews refuse to convert ${ }^{22}$.

Prima facie, these propositions embody an impressively tolerant attitude. Yet analysis quickly reveals there is less here than meets the eye. Theses 1 and 2 are unoriginal: the notion that the Jews' banishment from the Holy Land was a divine punishment was first articulated by Justin Martyr shortly after the Romans crushed the Bar Kokhba revolt in 135, while the claim that their rejection of Jesus fulfilled prophesy appears in the New Testament ${ }^{23}$. Both ideas were subsequently repeated by virtually all patristic writers. Thesis 6 was also stated and/or actually performed by many of Augustine's predecessors. And, as we have seen, thesis 5 was endorsed by Jerome. Hence, only theses 3 and 4 are markedly original.

It is also instructive to consider the witness doctrine in the larger context of Augustine's life and writings as a whole. Unlike Jerome, Augustine did not trouble himself to study Hebrew. Nor did he ever seek out the opinions of Jewish exegetes. His autobiographical Confessiones scarcely mentions Jews, while De civitate Dei affords Judaism in the Christian era only a single chapter. Among all his immense opera omnia - 230 books, 270 extant letters, more than 500 surviving sermons - there are only fifteen or so loci that outline the witness doctrine, and most of these are brief and fragmentary. By contrast, as we have noted, Augustine's exegetical works, and especially his sermons, are chockablock with anti-Jewish invective and polemic ${ }^{24}$. Even the pericope from the sermon on Psalm 59 quoted above - a key witness doctrine text - is not

\footnotetext{
factum est: per omnes gentes dispersi sunt Iudaei, testes iniquitatis suae et veritatis nostrae. Ipsi habent codices, de quibus prophetatus est Christus, et nos tenemus Christum. Et si quando forte aliquis paganus dubitaverit, cum ei dixerimus prophetias de Christo [...] de codicibus Iudaeorum probamus quia hoc tanto ante praedictum est. Videte quemadmodum de inimicis nostris alios confundimus inimicos", transl. by the author.

${ }^{22}$ Cf. Cohen, Living Letters of the Law, p. 41.

${ }^{23}$ Cf. Iustinus Martyr, Dialogus cum Tryphone Iudaeo 16, 2, PG 6, 509; e.g. Mt 13:13-15, Jn 12:37-38.

${ }^{24}$ On the very different rhetorical styles and strategies of Augustine's scholarly works versus the more demotic sermons, see B. Shaw, Sacred Violence, p. 280-281.
} 
free of it: he labels Jews as proud, contrasts "their iniquity" with "our truth", accuses them of slaying Christ, and thrice refers to them as inimici nostri.

Furthermore, Augustine agrees with Jerome in discerning an especially close nexus between Jews and Christian heretics. The Psalm sermons are especially rich in such analyses. Commenting on Psalm 57, for instance, he claims that Donatists are like Jews in their inability to speak or understand sacred truth ${ }^{25}$. In his sermon on Psalm 21, he argues that both have failed to understand the fulfillment of biblical prophecy in the world-wide spread of the Catholic Church ${ }^{26}$. And in several Psalm sermons Augustine draws parallels between the Jews' role in the crucifixion of Jesus and the damage Donatists do to the Church: both mocked the body ${ }^{27}$, divided its garments ${ }^{28}$ and broke its legs ${ }^{29}$. On dozens of occasions he uses nearly identical rhetoric to lambast Jews and Donatist for their arrogant myopia in believing they alone possess sacred truth.

Augustine also asserted close links between Jews and Pelagians. Here the core issue was grace versus personal merit in achieving salvation. In the 390s he sometimes wrote as if both had a role to play, but beginning about the turn of the century he began to argue salvation depended entirely upon divine grace ${ }^{30}$.

"God works in the hearts of humans beings to incline them withersoever he wishes - whether to good deeds according to his mercy, or to evil after their own deserts. His judgment is sometimes secret, sometimes manifest, but always righteous" ${ }^{\prime 31}$.

By contrast, he claimed, Jews and Pelagians alike deny grace and arrogantly believe they can earn salvation by obedience and personal moral rectitude. Commenting on Psalm 59:4, Augustine denounces this attitude in terms that clearly apply to both:

"There are «strong» people who base their self-assurance not on wealth, physical might, rank or worldly power, but on their own righteousness. We should always beware of this type, fear them, avoid them, and never imitate them"32.

\footnotetext{
${ }^{25}$ Cf. Augustinus, Enarrationes in Ps. 57, CCL 39, 712-714.

${ }^{26}$ Cf. ibidem 21, CCL 38, 121-122.

${ }^{27}$ Cf. ibidem 145, 6, CCL 40, 2116-2117.

${ }^{28} \mathrm{Cf}$. ibidem 21, 19, CCL 38, 127.

${ }^{29}$ Cf. ibidem 33, 7, CCL 38, 286.

${ }^{30} \mathrm{Cf}$. Brown, Augustine of Hippo, p. 141-148.

${ }^{31}$ Augustinus, De gratia et libero arbitrio 21, 43, PL 44, 909: "manifestatur operari Deum in cordibus hominum ad inclinandas eorum voluntates quocumque voluerit, sive ad bona pro sua misericordia, sive ad mala pro meritis eorum, iudicio utique suo aliquando aperto, aliquando occult, semper tamen iusto", transl. by the author.

${ }^{32}$ Idem, Enarrationes in Ps. 58, 7, CCL 39, 733: "Sunt et alii fortes, non de divitiis, non de viribus corporis, non de aliqua in tempore praecellenti potentia dignitatis, sed praesumentes de iustitia sua. Hoc genus fortium cavendum, metuendum, aversandum, non imitandum", transl. by the author.
} 
Here he directs his denunciation at the Jews:

"«Strength» of this kind has hindered the Jews from entering through the eye of the needle, for relying on themselves as righteous and considering themselves to be in good health, they refused the medicine and killed the physician" 33 .

Later in the same sermon, however, after arguing we must give up all pretense of personal strength and vowing to "place no reliance upon myself", Augustine suddenly asks: "What does the miserable Pelagius have to say to this?"34 Then, without skipping a beat, he pivots back to his discussion of the Jews. A letter from 418 is more explicit still:

"There are some like these who profess to be Christians, but are so hostile to the grace of Christ that they think they can fulfill the divine commandments by their own human strength. Thus, wanting to establish themselves as just, they are themselves ignorant of the justice of God and do not subject themselves to it. These are not Jews in name, but they have become so by their error. People of this sort have found leaders for themselves in Pelagius and Caelestius" 35 .

The paired, overlapping denunciations of Jews and heretics employed by Jerome and Augustine are examples of what David Hunter has termed "strategies for creating and maintaining symbolic worlds, which in turn sustained actual social and religious communities" $" 36$. In this case, such strategies made it possible for them to read the plaints of Israel's psalmists and prophets - plaints that in their original context were directed at the enemies of ancient Israel - as divinely inspired criticism of those who resisted the Church.

Linking the Church's enemies also helped Jerome and Augustine rhetorically to keep at bay their critics, as well as their own anxieties. Jerome's decision to base his translation of the Old Testament on what he provocatively termed the "Hebrew truth" rather than the Septuagint, as well as his practice of citing rabbinic opinions in his commentaries, meant he often faced accusations

${ }^{33}$ Ibidem: "Talis fortitudo impedivit Iudaeos ne per foramen acus intrarent. Cum enim de se praesumunt quod iusti sint, et tamquam sani sibi videntur, medicinam recusaverunt, et ipsum medicum necaverunt", transl. by the author.

34 Ibidem 58, 19, CCL 39, 743: "De me omnino nihil praesumam [...] Quid hic respondebit infelix Pelagius?" transl. by the author.

${ }^{35}$ Idem, Epistula 196, CSEL 57, 220: "His autem similes sunt, qui cum profiteantur se esse Christianos, ipsi gratiae Chisti sic adversantur, ut se humanis viribus divina existiment implere mandata, ac sic etiam ipsi ignorantes Dei iustitiam et suam volentes constituere iustitiae Dei non sunt subiecti et non quidem nomine sed tamen errore iudaizant. Hoc genus hominum capita sibi invenerat Pelagium et Caelestium", transl. by the author.

${ }^{36}$ D.G. Hunter, The Virgin, the Bride and the Church: Reading Psalm 45 in Ambrose, Jerome and Augustine, in: The Harp of Prophecy: Early Christian Interpretation of the Psalms, ed. B.E. Daley - S.J. and P.R. Kolbet, Notre Dame 2015, 150. 
of Judaizing ${ }^{37}$. Augustine, too, had a "Jewish problem"; in his case it stemmed from his unusual defense of the Mosaic Law's probity and efficacy in the preChristian era $^{38}$. Similarly, each man bore a stain of heterodoxy that proved almost impossible to wash out. Jerome's stemmed from his youthful embrace of all things Origen; Augustine's from his decade-long adherence to Manicheanism. As a result, both were forced to spend an inordinate amount of time - and spill an inordinate quantity of ink - refuting critics who claimed that traces of their old errors could still be detected in their work. These shared anxieties, as well as similar theological and ethical analyses, led both men to pair their advocacy of the Gospel with attacks on its enemies. Attacks that treated Jews and heretics as discrete groups assured their audience that they themselves were free either of Judaizing or heretical tendencies; attacks that blurred the distinction between the two demonstrated they were innocent of both.

Yet their stance toward these groups remained nuanced. Neither Jerome nor Augustine ever called for the forced conversion of Jews or heretics. Nor did they demand they be segregated or exiled.

Instead, for Augustine, the evil done by the inimici of God becomes an occasion for good. The Church receives unwitting testimony from the mouths of its enemies; the faithful are given vivid, visual warning that they too can fall; theologians and exegetes are motivated to deepen their knowledge of scripture and hone their arguments in support of Christian truth:

"[Heretics and apostates] turn out to benefit the true and catholic members of Christ by their evil, for God uses even the evil for good, and «all things work together for good for those who love him» (Rom 8:28). For all the Church's enemies, no matter how blinded by error or corrupted by malice, serve a useful purpose. If they have the power of inflicting bodily harm on the Church, they train it in patience; if they oppose it only by holding evil opinions, they train it in wisdom [... In both cases] they train it in benevolence and beneficence, so that even its enemies are loved"39.

Viewed in this light, the theory of Jewish witness emerges not as a sui generis exception, but rather as a subset of Augustine's larger theory of how God's enemies unwittingly serve his providence.

${ }^{37}$ Cf. Kelly, Jerome, p. 169. As early as 391, Jerome launched a fierce preemptive attack in the preface to his Liber quaestionum hebraicarum in Genesim (ed. P. de Lagarde, CCL 72, 3-4).

${ }^{38}$ Cf. J.J. O’Donnell, Augustine: A New Biography, New York 2005, 48-49.

${ }^{39}$ Augustinus, De civitate Dei 18, 51, ed. D. Dombart - A. Kalb, CCL 47, Turnhout 1955, 649: "Veris illis catholicis membris Christo malo suo prosunt, dum Deus utitur et malis bene et «diligentibus eum omnia cooperator in bonum». Inimici enim omnes ecclesiae, quolibet errore caecentur vel militia depraventur, si accipiunt potestatem corporaliter affligendi, exercent eius patientiam; si tantummodo male sentiendo adversantur, exercent eius sapientiam; ut autem etiam inimici diligantur, exercent eius benevolentiam aut etiam beneficentiam", transl. by the author. 
As for Jerome, he was clearly no match for Augustine as a speculative theologian. By 417 even he understood this. It was one reason he deferred to his North African colleague in the war against Pelagianism:

"It would be superfluous for me to repeat his words, but if I were to try to say something original, I should find he had anticipated my best points" ${ }^{\prime 40}$.

Yet as a pastor and an adept of the spiritual life, he knew well the dangers of pride and self-righteousness. In this sense, the failure of the Jews to recognize Jesus as Christ served as a salutary warning to Christians as well, lest they themselves fall prey to the smug self-assurance. What's more, the epistemological doubts Jerome shared with Augustine precluded any tendency to separate immediately the sheep from the goats. In this life, we can never know who ultimately or truly is a friend or enemy of God. Decades of spiritual reflection and pastoral experience had cured both men of their early, euphoric perfectionism. On the one hand, they had learned that even inveterate heretics, stubborn Jews and prideful pagans may convert. On the other, devout Christians might ultimately suffer damnation for future apostasy or for unrepented mortal sin. In this way, epistemological uncertainty produces a measure of tolerance. Hence, the role of a Christian pastor is not to condemn. Rather, he should preach faithfully the Gospel, resist the Church's enemies even while reaching out to them in love, and live a life of continual repentance. For he too is a sinner in need of mercy. As Jerome put it near the end of his life:

"The enemy continually assails us, and when conquered he does not depart, but rather lies in ambush, waiting to let fly his arrow and pierce the heart of the righteous" $"$.

Augustine's doubts were more radical still. Not only might the righteous fall; he may not even be righteous:

"Whoever does not want to fear, probe you conscience. Do not probe superficially; descend into yourself, penetrate your inmost heart. Explore diligently whether a poisoned vein of the wasting love of the world does not pulse, whether you are moved by sexual desire and are captive to some enticement, whether you are sometimes elated with empty boasting or depressed by vanity and worldly cares [...] Only when you have thoroughly scrutinized your conscience can you dare announce you are pure" ${ }^{\prime 42}$.

${ }^{40}$ Hieronymus, Dialogi contra Pelagianos 3, 19, CCL 80, 123: “Aut enim eadem dicemus ex superfluo, aut, si nova voluerimus dicere, a clarissimo ingenio occupata sunt meliora", transl. by the author.

${ }^{41}$ Ibidem 3, 1, CCL 80, 99: "Impugnat inimicus, nec victus recedit, sed semper insidiis est ut sagittet in occulto rectos corde", transl. by the author.

${ }^{42}$ Augustinus, Sermo 348, 2, PL 39, 1527: "Discute itaque conscientiam tuam, quisquis timere iam non vis. Noli superficiem compalpare, descende in te, penetra interior cordis tui. Rimare diligenter, utrum nulla ibi vena venenata tabificum amorem saeculi sugat et sorbeat, utrum nulla carnalis 


\section{(Summary)}

In their polemical as well as their ostensibly non-polemical writings, SS. Jerome and Augustine refer to the Church's enemies as an unholy triad: Jews, pagans, and Christian heretics. These inimici, they assert, are linked by their common failure to accept the Gospel of the orthodox Catholic Church, as well as by the root cause of their unbelief: pride, which leads them to resist the truth. In this article, I focus on the links Jerome and Augustine purport to find between Judaism and Christian heresy. I draw from polemical and non-polemical works by both writers, including Jerome's biblical commentaries and anti-Pelagian treatises, and Augustine's De Civitate Dei as well as his writings adversus Jews, Donatists, and Pelagians. In addition to identifying the doctrinal commonalities that Jerome and Augustine assert exist between Judaism and Christian heresy, I examine the often-similar rhetorical devices employed by both writers in their denunciations of these inimici. The article concludes by speculating on the possible roots of these denunciations in the authors' doubts and insecurities, and notes that, paradoxically, Jerome and Augustine's epistemological doubts regarding divine election led them to retain a measure of hope for their theological enemies, and so to counsel tolerance toward them.

\section{INIMICI NOSTRI: ŻYDZI JAKO HERETYCY \\ I HERETYCY JAKO JUDAIZUJACCY \\ U HIERONIMA I AUGUSTYNA}

\section{(Streszczenie)}

Hieronim i Augustyn w swych polemicznych, jak również rzekomo niepolemicznych pismach, odnoszą się do wrogów Kościoła jako do bezbożnej triady: Żydzi, poganie i chrześcijańscy heretycy. Twierdzą, że łączy ich (inimici) ze sobą negacja Ewangelii ortodoksyjnego Kościoła katolickiego, a także przyczyna ich niewiary - pycha, która prowadzi do odrzucania prawdy.

W tym artykule autor skupia się na powiązaniach, które Hieronim i Augustyn zdają się znajdować między judaizmem i chrześcijańską herezją. Korzysta z dzieł polemicznych i niepolemicznych obu pisarzy, w tym biblijnych komentarzy i antypelagiańskich traktatów Hieronima oraz De civitate Dei Augustyna, jak również jego pism przeciw Żydom, donatystom i pelagianom. Oprócz identyfikacji doktrynalnych podobieństw, które Hieronim i Augustyn wykazują między judaizmem i chrześcijańską herezją, autor analizuje również podobne często retoryczne figury stosowane przez nich w oskarżeniach na temat inimici. Na koniec zaś zastanawia się, czy możliwe przyczyny tego rodzaju wypowiedzi leżą w wątpliwościach tych

voluptatis movearis et capiaris illecebra, nulla inani iactantia tumidus extollaris, nulla cura vanitatis exaestues: audeas nuntiare purum ac liquidum te videre, quidquid latebrarum in conscientia perscrutaris", transl. by the author. 
Ojców, oraz zauważa, że paradoksalnie, niepewność epistemologiczna Hieronima i Augustyna doprowadziła ich do zachowania pewnej nadziei dla swych teologicznych wrogów, a w ten sposób do zalecania tolerancji względem nich.

Key words: Jerome, Augustine, Jews, heretics.

Słowa kluczowe: Hieronim, Augustyn, Żydzi, heretycy.

\section{BIBLIOGRAPHY}

\section{Sources}

Augustinus, De civitate Dei, ed. D. Dombart - A. Kalb, CCL 47-48, Turnhout 1955.

Augustinus, De gratia et libero arbitrio, PL 44, 881-912.

Augustinus, Enarrationes in Psalmos, ed. E. Dekkers - J. Fraipont, CCL 38-40, Turnhout 1956.

Augustinus, Epistulae 1-100, ed. K.-D. Daur, CCL 31, Turnhout 2004, CCL 31A, Turnhout 2005, CCL 31B, Turnhout 2009; Epistulae 124-184A, ed. A. Goldbacher, CSEL 44, Vindobonae - Lipsiae 1904; Epistulae 185-270, CSEL 57, Vindobonae - Lipsiae 1911. Augustinus, Sermones, PL 39.

Hieronymus, Commentarioli in Psalmos, ed. G. Morin, CCL 72, Turnhout 1959, 177-245. Hieronymus, Commentariorum in Osee prophetam libri, ed. M. Adriaen, CCL 76, Turnhout 1969, 1-158.

Hieronymus, Dialogi contra Pelagianos, ed. C. Moreschini, CCL 80, Turnhout 1990.

Hieronymus, Liber quaestionum hebraicarum in Genesim, ed. P. de Lagarde, CCL 72, Turnhout 1959, 1-56.

Iustinus Martyr, Dialogus cum Tryphone Judaeo, PG 6, 469-800.

\section{Literature}

Brown P., Augustine of Hippo, Berkeley $2000^{2}$.

Cohen J., Living Letters of the Law, Berkeley 1999.

Fredriksen P., Augustine and the Jews, New York 2008.

Hunter D.G., The Virgin, the Bride and the Church: Reading Psalm 45 in Ambrose, Jerome and Augustine, in: The Harp of Prophecy: Early Christian Interpretation of the Psalms, ed. B.E. Daley - P.R. Kolbet, Notre Dame 2015, 149-174.

Jews and Christians: The Parting of the Ways, A.D. 70-135, ed. J.D.B. Dunn, Grand Rapids 1999.

Kelly J.N.D., Jerome: His Life, Writings and Controversies, London 1975.

O’Donnell J.J., Augustine: A New Biography, New York 2005.

Partings: How Judaism and Christianity Became Two, ed. H. Shanks, Washington 2013.

SAlinero R.G., Biblia y polémica antijudía en Jerónimo, Madrid 2003.

Schmid J., SS. Eusebii Hieronymi et Aurelii Augustini epistulae mutuae, Bonn 1930.

SHaw B., Sacred Violence, Cambridge 2011.

Simon M., Verus Israel, Paris 1948.

Williams M.H., The Monk and the Book: Jerome and the Makings of Christian Scholarship, Chicago 2006. 
